\title{
Antimicrobial Susceptibility, Multilocus Sequence Typing, and Virulence of Listeria Isolated From A Slaughterhouse
}

\section{Liting Wu}

Jiangsu Academy of Agricultural Sciences

Hongduo Bao

Jiangsu Academy of Agricultural Sciences

Zhengquan Yang

Yangzhou University

Tao He

Jiangsu Academy of Agricultural Sciences

Yuan Tian

Jiangsu Academy of Agricultural Sciences

Yan Zhou

Jiangsu University

Maoda Pang

Jiangsu Academy of Agricultural Sciences

\section{Ran Wang}

Jiangsu Academy of Agricultural Sciences

Hui Zhang ( $\square$ huiZ@jaas.ac.cn )

Jiangsu Academy of Agricultural Sciences

\section{Research Article}

Keywords: Listeria, antimicrobial resistance, antimicrobial resistance genes, virulence, MLST

Posted Date: June 14th, 2021

DOl: https://doi.org/10.21203/rs.3.rs-590420/v1

License: (c) (i) This work is licensed under a Creative Commons Attribution 4.0 International License.

Read Full License 


\section{Antimicrobial susceptibility, Multilocus sequence typing, and}

\section{2 virulence of Listeria isolated from a slaughterhouse}

3

4

5

6 1

1. Jiangsu Key Laboratory for Food Quality and Safety-State Key Laboratory Cultivation Base of MOST, Jiangsu Academy of Agricultural Sciences, Nanjing 210014, China;

2. College of Food Science and Engineering, Yangzhou University, Yangzhou 225009, China 3. Jiangsu University - School of Food and Biological Engineering, Zhenjiang 212013, China

Corresponding author: Professor Hui Zhang Huiz@jaas.ac.cn

Mailing address: Institute of Food Safety and Nutrition, Jiangsu Academy of Agricultural Sciences,

No 50 Zhongling Street, Nanjing, Jiangsu 210014, China

Tel.: (+86) 25 84391627; fax: (+86) 2584391617. 


\section{Abstract}

Background: Listeria monocytogenes is one of the deadliest foodborne pathogens, and the bacterium can tolerate severe environments through biofilm formation and antimicrobial resistance. The objective of this study was to investigate the antimicrobial susceptibility, resistance genes,virulence and molecular epidemiology about Listeria from meat processing environments .

Methods: This study evaluated the antibiotic resistance and virulence of Listeria isolates from slaughtering and processing plants. All isolates were subjected to antimicrobial susceptibility testing by using a standard microbroth dilution method. The carrying of resistant genes were identified by Polymerase Chain Reaction (PCR). The multilocus sequence typing (MLST) was determined subtyping of the isolates and to characterize possible routes of contamination from meat processing environments. The virulence of different STs of $L$. monocytogenes isolates were evaluated by Caco-2 cells invasion assay.

Results: A total of 59 Listeria isolates were identified from 320 samples, including 37 L. monocytogenes $(62.71 \%)$. This study evaluated the virulence of L. monocytogenes and antibiotic resistance of Listeria isolates from slaughtering and processing plants. The susceptibility of these 59 isolates against eight antibiotics was analyzed, and the resistance levels to ceftazidime, ciprofloxacin, and lincomycin were as high as 98.31\% (L. m 37; L. innocua 7; L. welshimeri 14), 96.61\% (L. m 36; L. innocua 7; L. welshimeri 14), and 93.22\% (L. m 35; L. innocua 7; L. welshimeri 13) respectively. Over $90 \%$ of the isolates were resistant to 3-6 antibiotics, indicating that Listeria isolated from meat processing environments has high antimicrobial resistance. Up to $60 \%$ of the isolates carried the tetracycline-resistance genes tetA and tetM. The frequencies of ermA, ermB, erm C, and aac(6')-Ib were $16.95 \%, 13.56 \%, 15.25 \%$, and 
$426.78 \%$, respectively. Notably, the resistant phenotype and genotype did not match exactly, suggesting that the mechanisms of antibiotic resistance of these isolates were likely related to the processing environment. Multilocus sequence typing (MLST) revealed that 59 Listeria isolates were grouped into 10 sequence types (STs). The dominant L. monocytogenes STs were ST5, ST9, and ST121 in the slaughtering and processing plant of Jiangsu province. Moreover, ST5 subtypes exhibited high invasion in Caco-2 cells compared with ST9 and ST121.

Conclusions: The results of this study predict a prevalence of Listeria contamination in the slaughtering and processing plant, and resistance of the ST5 subtypes isolates to the antimicrobials may cause potential public health risks.

Keywords: Listeria, antimicrobial resistance, antimicrobial resistance genes, virulence, MLST 


\section{Background}

Listeria monocytogenes is one of the most important foodborne pathogens. The bacterium can infect humans and animals and can cause meningoencephalitis, abortion, and sepsis resulting in high rates of infection and mortality [1]. Due to its high degree of resistance in harsh conditions, L. monocytogenes is able to persist in food processing environments, such as meat, poultry, dairy, and seafood processing facilities, and the bacteria can proliferate during storage of chilled food products [1]. Sources and contamination patterns in various types of products have not yet been determined. Occurrence of L. monocytogenes in the food processing environment is variable, whereas its occurrence in food is generally around $5 \%-6 \%$ [2]. The food processing environment is easily contaminated by L. monocytogenes [3]. Molecular typing of isolates including Pulsed Field Gel Electrophoresis (PFGE) inside and outside a food processing facility can indicate potential sources of contamination from the external environment [4]. With the development of whole genome sequencing (WGS), multilocus sequence typing (MLST) has been widely used for the epidemiological investigation of L. monocytogenes and in source tracking of specific strains during outbreaks. Thus, the main ST subtypes can be analyzed more accurately $[5]$.

Antimicrobial resistance is a global public health problem [6,7]. L. monocytogenes rarely develops acquired resistance to antibiotics. However, researchers have 
reported that L. monocytogenes is resistant to antibiotics such as tetracycline, ciprofloxacin, erythromycin, and ampicillin [1]. Several studies have recently reported an increased rate of resistance to one or more clinically relevant antibiotics in environmental isolates $[8,9,10]$ and less frequently in clinical strains $[11,12]$. Due to the seriousness of multidrug resistance and the transmission of resistance genes between bacteria and across species, the prevalence of antimicrobial resistance is rising.

However, precise information concerning the ancestral and evolutionary linkage and genetic diversity of L. monocytogenes is not presently available. The advent of subtyping techniques, such as PGFE and WGS, has enabled source tracking of $L$. monocytogenes during outbreak investigations, but these technologies are not yet used for general surveillance in food supply chains due to their cost, complexity of analysis, and the expertise required to interpret such data. In the present study we used MLST, which can determine source of processing environment contamination through the analysis of the slaughtering operations, to trace the presence of $L$. monocytogenes in isolates from food commodities. The method allows us to perform subtyping of the pathogen and to characterize possible routes of contamination.

\section{Results}

\section{Occurrence of Listeria spp. in processing environment}

The overall prevalence of Listeria in slaughter and processing environments tested during the year 2019 is shown in Table 1. Thirty-seven isolates of L. monocytogenes, 7 isolates of L. innocua, and 15 isolates of L. welshimeri were obtained. The 59 
isolates were distributed in different areas: 7 from the slaughter area $(8.75 \%), 9$ from the cutting and deboning room (11.25\%), 23 from the visceral area $(28.75 \%)$, and 20 from the meat cooling and refrigeration area (25.00\%). A total of 59 Listeria isolates were recovered from 320 analyzed samples (18.44\%), including $37 \mathrm{~L}$. monocytogenes $(11.56 \%)$. The 59 isolates were distributed in different areas: 7 from the slaughter area $(8.75 \%), 9$ from the cutting and deboning room $(11.25 \%), 23$ from the visceral area $(28.75 \%)$, and 20 from the meat cooling and refrigeration area (25.00\%). A total of 59 Listeria isolates were recovered from 320 analyzed samples (18.44\%), including 37 L. monocytogenes $(11.56 \%)$. The highest percentage of $L$. monocytogenes strains (13) was found in samples taken from the cooling and refrigeration area (Table 1). Moreover, group $1 / 2 b$ was the main serotype $(12 / 37$, Table 2), and the next highest were $1 / 2 \mathrm{a}(7 / 37)$ and $1 / 2 \mathrm{c}(7 / 37)$, respectively. The others were $3 \mathrm{a}(3 / 37), 3 \mathrm{~b}(5 / 37)$, and $3 \mathrm{c}(3 / 37)$. From the above, serotypes $1 / 2 \mathrm{~b}, 1 / 2 \mathrm{a}$, and $3 \mathrm{~b}$ were the main endemic L. monocytogenes in slaughtering environments.

\section{Antimicrobial susceptibility testing}

The susceptibility of the 59 isolates to eight antibiotics was examined using the micro-broth dilution method. The results showed that isolates were resistant to ceftazidime (MIC $\geq 32 \mu \mathrm{g} / \mathrm{mL} ; 58 / 59,98.31 \%$ ), ciprofloxacin (MIC $\geq 64 \mu \mathrm{g} / \mathrm{mL}$; 57/59, 96.61\%), and lincomycin (MIC $\geq 4 \mu \mathrm{g} / \mathrm{mL} ; 55 / 59,93.22 \%$ ) (Table 3). Resistance to tetracycline reached $16.95 \%$ (MIC $\geq 16 \mu \mathrm{g} / \mathrm{mL} ; 10 / 59)$. Very few isolates were resistant to gentamicin (MIC $16 \mu \mathrm{g} / \mathrm{mL}$; 2/59) or ampicillin (MIC 32 $\mu \mathrm{g} / \mathrm{mL} ; 1 / 59)$. Noteworthy was the intermediate resistance against erythromycin 
$(\mathrm{MIC}=1-4 \mu \mathrm{g} / \mathrm{mL} ; 29 / 59)$ observed in these isolates . All of the isolates were highly susceptible to vancomycin $(100 \%)$. Multidrug resistance showed that 58 strains were resistant to at least two antibiotics. Only one isolate (LM3-2) of $L$. welshimeri was susceptible to all antibiotics. The proportion of the strains resistant to three kinds of antibiotics was $76.27 \%$, and the proportion for 3-6 antibiotics was $91.38 \%$. The $L$. welshimeri isolate LM3-7 from the slaughter area was resistant to six antibiotics, and the resistance was the most serious in this study (Fig. 1, Fig. 2).

Prevalence of 11 resistance genes was assessed, and the results are summarized in Table 3. In the slaughtering and processing environment, the genes tetA, tetM, ermA, $\operatorname{erm} B, \operatorname{erm} C$, and $a a c\left(6^{\prime}\right)-I b$ were detected in different areas. The tetS, mecA, vanA, $v a n B$, and $c f r$ genes were not detected in all Listeria isolates. Tetracycline resistance genes tetA $(61.3 \%)$ and tetM $(45.3 \%)$ were the two most commonly detected antibiotic resistance genes. The erythromycin resistance gene cassette, including ermA (16.95\%), ermB (13.56\%), and ermC (15.25\%), was present among $L$. monocytogenes, L. welshimeri, and L. innocua. Four isolates of Listeria were found to carry $a a c\left(6^{\prime}\right)-I b$ by detecting the resistance gene for aminoglycosides. However, the resistant genotypes and phenotypes were not exactly the same (Table 4, Fig. 3). In comparison, there were 58 strains of ceftazid-resistant isolates, but none of these isolates presented known resistance genes (Table 3).

\section{MLST}

A total of 59 Listeria isolates were classified into 11 sequence types (STs) (Fig. 4). Seventeen L. monocytogenes belonged to ST5 (17/37, 45.95\%). Other STs belonged 
to ST9 (10/37) and ST121 (10/37). The remaining 22 non-L. monocytogenes isolates were grouped into ST540, ST602, ST637, ST537, ST10057, ST168, and ST1084. The most endemic ST was ST5, which was isolated from four areas. ST121 was widely distributed in the meat cooling and refrigeration area (D). Seven L. innocua isolates were divided into five STs, three of which belonged to ST537. Fifteen $L$. welshimeri isolates were divided into ST1005, ST1084, and ST168. The 17 isolates of L. monocytogenes ST5 were serotype $1 / 2 \mathrm{~b}$, and five belonged to serotype $3 \mathrm{~b}$. Among the 10 ST9 isolates, three belonged to $3 \mathrm{c}$, and seven belonged to $1 / 2 \mathrm{c}$. The serotypes of ST121 consisted of seven isolates of $1 / 2 \mathrm{a}$ and three isolates of $3 \mathrm{a}$. We found that isolates classified as the same serogroup could be differentiated into different STs. This finding may be applied to other isolates of L. monocytogenes.

\subsection{Virulence genes and invasion assays}

In this study, the virulence and invasiveness of L. monocytogenes were evaluated by invasion assays. Seven virulence associated genes, $\operatorname{prf} A, p l c A, \operatorname{gyr} B, p l c B$, inlA, hly, and $\operatorname{sig} B$, were detected by PCR. Each of the seven virulence-associated genes was detected in all L. monocytogenes strains. The invasion efficiency of the isolates ranged from $0.002 \%$ to $1.295 \%$. The results showed that the isolates within the same STs had different levels of invasiveness against Caco-2 cells. The invasion frequencies of ST5 and ST121 ranged from $0.004 \%$ to $1.159 \%$ and $0.012 \%$ to $1.295 \%$, respectively. The invasion frequency of ST9 was relatively lower than that of ST5 and ST121, from $0.002 \%$ to $0.669 \%$. The average invasion frequency of ST9 was $0.1406 \%$, whereas the values for ST5 and ST121 were $0.4419 \%$ and $0.4332 \%$, 
respectively (Fig. 5). The ST5 isolates mainly came from the cutting and deboning room and visceral area regions and showed higher levels of invasiveness.

\section{Discussion}

L. monocytogenes, ubiquitous in the environment, is the causative agent of listeriosis. Although incidence of the disease is low compared to those by other foodborne pathogens, the disease outcome is often more serious [13]. Food safety regulations in many countries have tended to adopt a zero tolerance policy for L. monocytogenes in ready-to-eat (RTE) food products, as human listeriosis outbreaks have been most often associated with RTE products that are consumed without prior cooking. RTE meat products contaminated with Listeria might be the result of cross-contamination during processing and handling during storing, slicing, weighing, and packaging [14]. In this study, we investigated the resistance and STs of the Listeria isolated from the slaughter and processing environment in Jiangsu province, China. Fifty-nine Listeria strains were found in 320 samples from the slaughterhouse (18.44\%), including 37 of L. monocytogenes (37), seven of L. innocua (7), and 15 of L. welshimeri (15). However, from previous reports, 19 cheese factories $(55.8 \%)$ were contaminated by Listeria spp., demonstrating a higher contamination rate compared with our results. Of these, $20.6 \%$ were L. monocytogenes positive, while in our data the proportion reached $62.71 \%$. Moreover, L. monocytogenes was found on $4.9 \%$ of product contact surfaces and $18.8 \%$ of floor drains [15]. In Romania, meat processing plants were contaminated at higher rates of L. monocytogenes (18.8\% and $26.5 \%)[16,17,18]$. Vongkamjan et al. also demonstrated that L. monocytogenes occurred (35\%) in 
environmental samples from one seafood processing plant. Therefore, the environmental surfaces appear to be easier to contaminate than the food matrices [19]. In our study, prevalence of L. monocytogenes in meat cooling and refrigeration areas (D) was significantly higher than in other areas in 2018. The suggestion that $L$. monocytogenes grows well at low temperatures should be remembered. Therefore, periodic surveillance and sanitation should be strictly implemented to improve the hygiene conditions of the slaughter and processing environment to achieve higher food safety levels.

Previous studies have reported that L. monocytogenes from seafood processing plants belonged to serotypes $1 / 2 \mathrm{~b}, 3 \mathrm{~b}, 4 \mathrm{~b}, 4 \mathrm{~d}$, and $4 \mathrm{e}[15,20,21]$, and serotypes $1 / 2 \mathrm{~b}$, $1 / 2 \mathrm{a}, 4 \mathrm{~b}$, and $1 / 2 \mathrm{c}$ are usually found in meat products and meat processing plants [22]. Skowron et al. found that most $(38.6 \%)$ isolates in a fish processing plant belonged to the group $1 / 2 \mathrm{a}-3 \mathrm{a}$ [13]. Among our results, the majority of the isolates belonged to serotypes $1 / 2 \mathrm{~b}(35.14 \%), 1 / 2 \mathrm{a}$, and $1 / 2 \mathrm{c}(18.92 \%)$, which are the serotypes that are predominantly found in food. Serotype $4 \mathrm{~b}$ is mainly from listeriosis patients and was not found in these isolates.

The antimicrobial resistance of $L$. monocytogenes is usually low $(2 \%-3 \%)[20,23]$. However, several studies have shown that up to $7.1 \%$ of strains resistant to antibiotics is not uncommon in fish processing plants [13]. In our results, the commonly used antibiotics CAZ, CIP, and LIN were generally ineffective against resistant $L$. monocytogenes isolates. We speculate that the reason is that antibiotics have been used in the breeding process. With the emergence of strains carrying 
antibiotic resistance genes, such genes can be transferred between strains via plasmids. Multidrug resistance tests indicated that $90 \%$ of the isolates were resistant to more than two antibiotics, meaning that antimicrobial resistance in Listeria is still at a low prevalence compared with the meat processing environment [7]. In recent years, a growing body of evidence suggests that the resistant bacteria produced in the processing environment may affect antibiotic resistance transfer in human pathogens through the food products. Although many L. monocytogenes strains from humans are susceptible to antimicrobials, our results illustrate how new isolates can become resistant to commonly used antimicrobials.

In the present study, we first described the multiple resistance genes tetA, tetM, ermA, ermB, erm $C$, and $a a c\left(6^{\prime}\right)-I b$ of $L$. monocytogenes isolated from the slaughter and processing environment. In general, tet $B$ and tet $M$ were frequently detected in mobile plasmids [24]. In our study, tet $A$ and tet $M$ were the major phenotypes, and these were significantly enhanced compared with previous studies, suggesting a potential connection of tetA and tet $M$ with multidrug resistance bacteria. MDR $L$. monocytogenes isolated from frozen food products has shown harboring the multiple resistance ermB and tet $S$ genes [8]. Moreover, certain antibiotic resistance genes such as tetM can be transferred among bacterial communities in various environments [25,26,27]. Horizontal gene transfer among humans and the environment is possible. The $c f r$ gene was not identified in any of the 59 isolates, although this gene is commonly found in staphylococci isolates from humans and animals [28]. Many reports of $c f r$ genes come from China, mostly from animals. 
However, there are few reports concerning the $c f r$ gene in Listeria. Our analysis of resistant Listeria phenotypes and resistance genotypes found that the coincidence rate was inconsistent (Table 2), which may be due to the existence of multiple resistance mechanisms. In present study, Listeria isolates were resistant to ampicillin (1.69\%), erythromycin (49.15\%), gentamicin (3.39\%), and tetracycline (16.95\%).

The present findings were in partial correlation with that of Yadav et al. [29] who reported resistance to ampicillin, erythromycin, gentamicin and tetracycline to be $22.92 \%, 16.67 \%, 31.25 \%, 10.42 \%$, respectively. Kumar et al. [30] reported that the multidrug-resistant Listeria isolated from meat and fish had observed sensitivity $(66.66 \%)$ for ciprofloxacin. However, our research shows that the sensitivity of ciprofloxacin was $3.39 \%$. In present investigation there were $91.38 \%$ strains of Listeria spp. that were resistant to 3-6 antibiotics. So it is of great concern that this expanding range of antibiotics now includes those drugs that is used for treatment of human and animal listeriosis. The high number of multiple drug resistant strains of Listeria found in this study seems to suggest that mobile genetic elements encoding resistance to a wide range of antibiotics in this genus have appeared and are spreading. The resistance mechanisms of bacteria are very complex. The location of resistance genes (on plasmids or chromosomes), genetic structure, expression level, interactions between different resistance genes, and formation of bacterial biofilms affect bacterial resistance to antibiotics. The resistance of bacteria to a drug may result from the combination of several resistance genes and resistance mechanisms [31]. Some studies have shown that L. monocytogenes can obtain resistance genes 
252 from the environment through plasmids and transposons, leading to the gradual 253 increase of L. monocytogenes resistance [32]. Due to differences in the actual gene 254 expression levels or antibiotic metabolism, strains carrying the same antibiotic 255 resistance genotype may have different resistant phenotypes.

256 MLST plays an important role in analysis of the mode of contamination and 257 transmission routes of Listeria. Different studies have shown that the currently 258 separated STs in the processing environment of China are ST5, ST199, ST8, ST9, 259 ST121, ST3, and ST224. Wang et al. found that the most common STs of $L$. monocytogenes in China were ST8 and ST9, and the main ST of L. monocytogenes 261 isolated from chicken and pork was ST9 [33]. Compared with European countries, the STs in the food processing environment mainly include ST1, ST9, ST87, ST5, ST7, ST37, ST570, and ST204. However, our study found that the major STs were ST5, ST9, and ST121. Almost all of ST9 and ST121 isolated were from the visceral area (C) and the meat cooling and refrigeration area (D). ST5 was isolated from all areas, indicating that ST5 plays an important role in the entire processing

267 environment. The $\mathrm{C}$ and $\mathrm{D}$ areas in the slaughtering processing environment contained large numbers of ST9 and ST121, indicating that ST9 and ST121 from RTE meat products may originate from processing raw meat in the processing environment. In a study of 300 clinical, food, and environmental sources of isolates

271 from 42 countries on five continents, CC9 was the fourth most common CC in the 272 world, ranking third in Europe after CC1, CC2 and CC3 [34]. In our study, among 273 the seven housekeeping gene alleles, more than five identical alleles were present 
274 from a clonal complex. The main clonal complexes present in this study were CC5,

275 CC9, and CC121. In the L. monocytogenes strains CC9 and CC121, premature stop 276 codons leading to truncation of the virulence gene inlA are often present. The $L$.

277 monocytogenes STs are assigned to the latter cells and are considered to be more

278 suitable for environmental conditions. Lineage II bacteria, including the most 279 dominant worldwide strain CC121, are the main STs reported in human sporadic 280 listeriosis. ST5, ST9, and ST121 included resistant isolates and resistance genes, 281 suggesting that monitoring of potentially pathogenic STs should be strengthened. 282 ST5 has been associated with human listeriosis outbreaks, and ST9 is predominant in 283 China $[33,35,36]$, indicating that L. monocytogenes that exist in the slaughtering and 284 processing environment share a common source with humans. In present study, $L$. 285 inocua (7 isolates) and L. welshimeri (15 isolates) were isolated from 320 samples of 286 slaughterhouse. Antunes et al. [37] found that Listeria spp. were present in all 63 $287(100 \%)$ poultry samples, including L. innocua (32 isolates), L. welshimeri (8 288 isolates). Yadav et al. [29] reported that the 20 strains of L. inocua were isolated 289 from 2417 animals and its surrounding environment samples. Thus it can be seen, 290 the pattern of susceptibility between L. monocytogenes and L. innocua is important, 291 owing to the fact that both species are usually found in the same food or food 292 processing environment [7].

\section{Conclusions}

294 In conclusion, the presence of serogroups $1 / 2 \mathrm{a}, 3 \mathrm{a}$ and $1 / 2 \mathrm{~b}, 3 \mathrm{~b}$, as well as the resistance and pathogenic STs, is associated with human listeriosis. The findings in 
this study illustrate a potential public health risk in the slaughtering and processing environment. Antimicrobial resistance is increasing in foodborne pathogens. We found three new STs in Jiangsu province, highlighting the need to fill out the MLST database by increasing the surveillance of $L$. monocytogenes worldwide.

\section{Materials and methods}

\section{Sample collection and isolation of Listeria}

A total of 320 environmental swabs were collected from a pig slaughtering and processing environment in 2019. The slaughtering and processing region can be divided into four areas: slaughter, carcass partition, visceral separation, and meat cooling and cryopreservation. Sampling included both food contact surfaces (FCS) and non-food contact surfaces (NFCS), including flooring, tables, walls, conveyor belts, trays, carts, and sinks (Rückerl et al., 2014). 320 environmental samples were collected in two times in four regions, including 80 from slaughter ( flooring, carcass surface with pig hair, blood, sinks), 80 from carcass partition (carcass, cutting knife, conveyor) before their cleaning, 80 from visceral separation (cutting knife, tables, trays, walls), 80 from meat cooling and cryopreservation (flooring, tables, trays, carts, belts, walls). About $100 \mathrm{~cm} 2$ of plane surfaces were swabbed two to five times using sterile cotton-tipped applicators moistened with $0.1 \%$ peptone water. The two to five swabs were pooled as one sample. Effluent was collected using sterile sampling bags. All of the samples were loaded in a refrigerated vehicle and transported to the lab within $24 \mathrm{~h}$. Listeria was isolated according to the National

Standard of China GB 4789.30-2016. For detection of Listeria spp., $25 \mathrm{~g}$ of 
slaughterhouse sample was enrichment in semi-concentrated Fraser Broth (Merck,Germany) (Primary Selective Broth) at $37{ }^{\circ} \mathrm{C}$ for $24 \mathrm{~h}$ followed by transferring the $0.1 \mathrm{ml}$ of initial base solution to $10 \mathrm{ml}$ of Fraser Broth (secondary selective broth) and incubation at $37{ }^{\circ} \mathrm{C}$ for $24 \mathrm{~h}$. Secondly enrichments were streaked onto Oxford agar (Merck, Germany) and Palcam agar (Merck, Germany) and incubated at $35{ }^{\circ} \mathrm{C}$ for $48 \mathrm{~h}$. The plates were examined for Listeria colonies (black colonies with black sunken center) and at least three suspected colonies were subcultured onto Trypton Soy agar supplemented with $0.6 \%$ of yeast extract (TSAYE) (Merck, Germany) and incubated at $37{ }^{\circ} \mathrm{C}$ for $24 \mathrm{~h}$. All of the isolates were confirmed to morphological characteristics of colonies and single bacterial cells after the Gram staining, catalase test and motility test (in Listeria Motility Medium (Merck, Germany) after the incubation at $25^{\circ} \mathrm{C}$ for $2-5$ days). Serotyping of $L$. monocytogenes was carried out by the serum agglutination test according to the Listeria antisera of antigen 0 and flagellar antigen H (Denka Seiken Co. LTD.).

\section{Antimicrobial susceptibility testing}

Minimum inhibitory concentrations of Listeria isolates were determined by using the micro-broth dilution method recommended by the Clinical and Laboratory Standard Institute (CLSI, 2014). The following antimicrobial agents (Solarbio Ltd., China) were used in this study (range in $\mu \mathrm{g} / \mathrm{mL}$ ): gentamicin (GEN; 1-128), ampicillin (AMP; 2-128), ceftazidime (CAZ; 2-128), ciprofloxacin (CIP; 0.25-64), tetracycline (TET; 1-64), erythromycin (ERY; 0.25-16), lincomycin (LIN; 0.25-32), and vancomycin (VAN; 1-128). Streptococcus pneumonia ATCC 49619 was selected as a 
340

quality control strain. tetA, tet $M, \operatorname{tet} S, \operatorname{erm} A, \operatorname{erm} B, \operatorname{erm} C, \operatorname{aac}\left(6^{\prime}\right)-I b, \operatorname{mec} A, \operatorname{van} A$, $v a n B$, and $c f r$ were selected as specific resistance genes and were identified by PCR (Table 5).

\section{Multilocus sequence typing (MLST)}

MLST based on seven housekeeping genes (abcZ, bglA, cat, dapE, dat, ldh, and lhkA) was performed according to the method of Wang et al. [33] The scheme and genotypic data are available at http://bigsdb.web.pasteur.fr/listeria/. Minimum spanning tree analysis was inferred using BioNumerics (Version 5.10, Applied Maths, Belgium).

\section{Virulence gene and invasion assays in vitro}

Virulence genes $\operatorname{prf} A, \operatorname{plcA}, \operatorname{gyr} B, \mathrm{plcB}$, inlA, hly, and $\operatorname{sig} B$ of L. monocytogenes were identified by PCR as described previously [31,38]. Primers and the size of each amplified product are listed in Table 6. Invasiveness of these isolates was measured by using the human colorectal adenocarcinoma cell line Caco-2. In brief, Caco-2 cells $\left(3.0 \times 10^{5}\right.$ cells per well $)$ were cultured in 24 -well plates in Dulbecco's modified Eagle medium (DMEM) (Gibco; Invitrogen, Carlsbad, CA, USA) containing $10 \%$ calf serum (Invitrogen) at $37^{\circ} \mathrm{C}$ in an incubator supplemented with $5 \%$ carbon dioxide $\left(\mathrm{CO}_{2}\right)$. Isolates of L. monocytogenes were grown in BHI broth under cultivation conditions of $30^{\circ} \mathrm{C}$ for $18 \mathrm{~h}$. Cell monolayers were infected with $1.0 \times 10^{7}-2.0 \times 10^{7}$ L. monocytogenes cells/well for $30 \mathrm{~min}$, followed by three washes with Dulbecco's phosphate-buffered saline (DPBS). After incubating for $45 \mathrm{~min}$, monolayers were overlaid with DMEM containing $100 \mu \mathrm{g} / \mathrm{mL}$ gentamycin to kill 
362 extracellular bacteria. After incubating for $90 \mathrm{~min}$, cells were washed three times

363 with DPBS. Then, $1 \mathrm{~mL}$ of ice-cold distilled water was added, and viable

364 intracellular bacteria were enumerated by plating appropriate dilutions of the cell

365 lysate on BHI agar. At least three independent invasion assays were performed for

366 each isolate. Invasion efficiency was calculated as the percentage of the inoculum

367 recovered from the infected Caco-2 cells by the enumeration of intracellular bacteria

368 [31].

369

370

371

372 
374 Table 1 Isolation frequency of Listeria from pig slaughter factory

\begin{tabular}{|c|c|c|c|}
\hline Sample type & No. of samples & No. of Listeria & No. of positive samples (\%) \\
\hline Slaughter area (A) & 80 & $\begin{array}{l}\text { L. monocytogenes }(6) \\
\text { L. innocua }(1)\end{array}$ & $8.75(7)$ \\
\hline Visceral area $(\mathrm{C})$ & 80 & $\begin{array}{l}\text { L. monocytogenes }(11) \\
\text { L. innocua }(1) \\
\text { L. welshimeri }(11)\end{array}$ & $28.75(23)$ \\
\hline Meat cooling and refrigeration area (D) & 80 & $\begin{array}{l}\text { L. monocytogenes }(13) \\
\text { L. innocua }(3) \\
\text { L. welshimeri }(4)\end{array}$ & $25.00(20)$ \\
\hline Total & 320 & $\begin{array}{l}\text { L. monocytogenes }(37) \\
\text { L. innocua }(7) \\
\text { L. welshimeri }(15)\end{array}$ & $18.44(59)$ \\
\hline
\end{tabular}

Phylogenetic groups of tested L. monocytogenes strains $(\mathrm{n}=59)$ 
Table 2 Serotypes and isolation regions of $L$. monocytogenes isolates

Number of L. monocytogenes isolates [n(\%)]

\begin{tabular}{|c|c|c|c|c|c|}
\hline Group & Slaughter area (A) & $\begin{array}{l}\text { Cutting and deboning } \\
\text { room (B) }\end{array}$ & Visceral area $(\mathrm{C})$ & $\begin{array}{l}\text { Meat cooling and } \\
\text { refrigeration area (D) }\end{array}$ & Total \\
\hline $1 / 2 \mathrm{a}$ & ND & ND & LM3-11 & $\begin{array}{l}\text { LM1, LM2, LM3, } \\
\text { LM6, LM7, LM8, }\end{array}$ & $7(18.91 \%)$ \\
\hline $1 / 2 b$ & $\begin{array}{l}\text { LMA1, LMA8, } \\
\text { LMA9, LMA13, LMA-II }\end{array}$ & LMB4, LMB-I & $\begin{array}{l}\text { LMC4, LMC9, } \\
\text { LMC15, LMC-I }\end{array}$ & LMD3, LMD10 & $13(35.14 \%)$ \\
\hline $1 / 2 \mathrm{c}$ & ND & LM2-18 & $\begin{array}{l}\text { LM3-2-2,LM3-19, } \\
\text { LM3-20-2 }\end{array}$ & $\begin{array}{l}\text { LM1T7, LM2T3, } \\
\text { LM2W3 }\end{array}$ & $\begin{array}{c}7 \\
(18.92 \%)\end{array}$ \\
\hline $3 a$ & LM1-9 & ND & LMC11 & LM4 & $\begin{array}{c}3 \\
(8.11 \%)\end{array}$ \\
\hline $3 c$ & ND & ND & LMX-3, LMC7 & LM1W3 & $\begin{array}{c}3 \\
(8.11 \%)\end{array}$ \\
\hline $3 b$ & ND & $\begin{array}{l}\text { LMB5, LMB9, } \\
\text { LMB10, LMB13 }\end{array}$ & ND & ND & $\begin{array}{c}4 \\
(10.81 \%)\end{array}$ \\
\hline Total & 6 & 7 & 11 & 13 & $\begin{array}{c}37 \\
(100 \%)\end{array}$ \\
\hline
\end{tabular}

ND represents "None determined 


\begin{tabular}{|c|c|c|c|c|c|c|}
\hline \multicolumn{7}{|c|}{ Source and no. of resistant strains (\%) } \\
\hline \multicolumn{2}{|c|}{$\begin{array}{l}\text { Antibitocs } \\
(\mathrm{ug} / \mathrm{ml})\end{array}$} & $\begin{array}{l}\text { Slaughter area } \\
\qquad n=7\end{array}$ & $\begin{array}{l}\text { Cutting and deboning room } \\
\qquad n=9\end{array}$ & $\begin{array}{l}\text { Visceral area } \\
\quad n=23\end{array}$ & $\begin{array}{l}\text { Meat cooling and refrigeration } \\
\text { area } \\
n=20\end{array}$ & Total \\
\hline \multirow[t]{3}{*}{ GEN } & $R \geqslant 16$ & $0(0.00 \%)$ & $0(0.00 \%)$ & L. welshimeri (1) (4.35\%) & L. welshimeri (1) (5.00\%) & $2(3.39 \%)$ \\
\hline & $\mathrm{I}=8$ & $0(0.00 \%)$ & $0(0.00 \%)$ & $\operatorname{L.m}(1)(4.35 \%)$ & $0(0.00 \%)$ & $1(1.69 \%)$ \\
\hline & $S \leqslant 4$ & $\begin{array}{c}\text { L. innocua }(1) \\
\text { L. } m(6)(100.00 \%)\end{array}$ & $\begin{array}{c}\text { L. innocиа }(2) \\
\text { L. } m(7)(100.00 \%)\end{array}$ & $\begin{array}{c}\text { L. innocua (1) L. welshimeri (9) } \\
\text { L. } m(11)(91.30 \%)\end{array}$ & $\begin{array}{c}\text { L. innocua (3) L. welshimeri (3) } \\
\text { L. } m(13)(95.00 \%)\end{array}$ & $56(94.92 \%)$ \\
\hline \multirow[t]{3}{*}{ CAZ } & $R \geqslant 32$ & $\begin{array}{l}\text { L. innосиа }(1) \\
\text { L. } m(6)(100.00 \%)\end{array}$ & $\begin{array}{c}\text { L. innocua }(2) \\
\text { L. } m(7)(100.00 \%)\end{array}$ & $\begin{array}{c}\text { L. innocua (1) L. welshimeri }(10) \\
\text { L. } m \text { (11) }(95.65 \%)\end{array}$ & $\begin{array}{c}\text { L. innocua (3) L. welshimeri (4) } \\
\text { L. } m(13)(100.00 \%)\end{array}$ & $58(98.31 \%)$ \\
\hline & $\mathrm{I}=16$ & $0(0.00 \%)$ & $0(0.00 \%)$ & $0(0.00 \%)$ & $0(0.00 \%)$ & $0(0.00 \%)$ \\
\hline & $\mathrm{S} \leqslant 8$ & $0(0.00 \%)$ & $0(0.00 \%)$ & L. welshimeri (1) (4.35\%) & $0(0.00 \%)$ & $1(1.70 \%)$ \\
\hline \multirow[t]{3}{*}{ AMP } & $R \geqslant 32$ & $\begin{array}{l}\text { L. } m(1) \\
(14.29 \%)\end{array}$ & $0(0.00 \%)$ & $0(0.00 \%)$ & $0(0.00 \%)$ & $1(1.69 \%)$ \\
\hline & $I=16$ & $0(0.00 \%)$ & $0(0.00 \%)$ & $0(0.00 \%)$ & $0(0.00 \%)$ & $0(0.00 \%)$ \\
\hline & $\mathrm{S} \leqslant 8$ & $\begin{array}{c}\text { L. innocua }(1) \\
\text { L. } m(5)(85.71 \%)\end{array}$ & $\begin{array}{l}\text { L.innocua }(2) \\
\text { L. } m(7)(100.00 \%)\end{array}$ & $\begin{array}{c}\text { L. innocua (1) L. welshimeri (11) } \\
\text { L. } m(11)(100.00 \%)\end{array}$ & $\begin{array}{c}\text { L. innocua (3) L. welshimeri (4) } \\
\text { L. } m(13)(100.00 \%)\end{array}$ & $58(98.31 \%)$ \\
\hline CIP & $\mathrm{R} \geqslant 4$ & $\begin{array}{l}\text { L. innocua }(1) \\
\text { L. } m(6)(100.00 \%)\end{array}$ & $\begin{array}{l}\text { L. innocua }(2) \\
\text { L. } m(6)(88.89 \%)\end{array}$ & $\begin{array}{c}\text { L. innocua (1) L. welshimeri }(10) \\
\text { L. } m(11)(95.65 \%)\end{array}$ & $\begin{array}{c}\text { L. innocua (3) L. welshimeri (4) } \\
\text { L. } m(13)(100.00 \%)\end{array}$ & $57(96.61 \%)$ \\
\hline
\end{tabular}




\begin{tabular}{|c|c|c|c|c|c|c|}
\hline & $\mathrm{I}=2$ & $0(0.00 \%)$ & $0(0.0 \%)$ & L. welshimeri (1) $(4.35 \%)$ & $0(0.0 \%)$ & $1(1.69 \%)$ \\
\hline & $\mathrm{S} \leqslant 1$ & $0(0.00 \%)$ & L. $m(1)(11.11 \%)$ & $0(0.00 \%)$ & $0(0.00 \%)$ & $1(1.69 \%)$ \\
\hline \multirow[t]{3}{*}{ TET } & $R \geqslant 16$ & L. $m(1)(14.29 \%)$ & $\begin{array}{l}\text { L. innocua }(2) \\
\text { L. } m(1)(33.33 \%)\end{array}$ & $\begin{array}{c}\text { L. innocua (1) L. welshimeri (2) } \\
\text { L. } m(1)(17.39 \%)\end{array}$ & $\begin{array}{l}\text { L. innocua }(1) \\
\text { L. } m(1)(10.00 \%)\end{array}$ & $10(16.95 \%)$ \\
\hline & $\mathrm{I}=8$ & $0(0.00 \%)$ & $0(0.00 \%)$ & $0(0.00 \%)$ & $0(0.00 \%)$ & $0(0.00 \%)$ \\
\hline & $S \leqslant 4$ & $\begin{array}{l}\text { L. innocua }(1) \\
\text { L. } m(5)(85.71 \%)\end{array}$ & L. $m(6)(72.7 \%)$ & $\begin{array}{l}\text { L. welshimeri }(9) \\
\text { L. } m(10)(82.61 \%)\end{array}$ & $\begin{array}{l}\text { L. innocua (2) L. welshimeri (4) } \\
\text { L. } m(12)(90.00 \%)\end{array}$ & $49(83.05 \%)$ \\
\hline \multirow[t]{3}{*}{ ERY } & $R \geqslant 8$ & $0(0.00 \%)$ & $0(0.00 \%)$ & $\begin{array}{l}\text { L. welshimeri }(1) \\
\text { L. } m(1)(8.70 \%)\end{array}$ & $\begin{array}{l}\text { L. welshimeri }(1) \\
\text { L. } m(1)(10.00 \%)\end{array}$ & $4(6.78 \%)$ \\
\hline & $\mathrm{I}=1-4$ & L. $m(2)(28.57 \%)$ & $\begin{array}{l}\text { L. innocua }(2) \\
\text { L. } m(4)(66.67 \%)\end{array}$ & $\begin{array}{c}\text { L. innocua (1) L. welshimeri (7) } \\
\text { L. m (3) }(47.83 \%)\end{array}$ & $\begin{array}{l}\text { L. welshimeri (2) L. } m(8) \\
(50.00 \%)\end{array}$ & $29(49.15 \%)$ \\
\hline & $\mathrm{S} \leqslant 0.5$ & $\begin{array}{l}\text { L. innocua }(1) \\
\text { L. } m(4)(71.43 \%)\end{array}$ & L. $m(3)(33.33 \%)$ & $\begin{array}{l}\text { L. welshimeri }(3) \\
\text { L. } m(7)(43.48 \%)\end{array}$ & $\begin{array}{c}\text { L. innocua (3) L. welshimeri(1) } \\
\text { L.m (4) }(40.00 \%)\end{array}$ & $26(44.07 \%)$ \\
\hline \multirow[t]{3}{*}{ LIN } & $R \geqslant 4$ & $\begin{array}{l}\text { L. innocua }(1) \text { L. } m(5) \\
(85.71 \%)\end{array}$ & $\begin{array}{l}\text { L. innocua }(2) \\
\text { L. } m(7)(100.00 \%)\end{array}$ & $\begin{array}{c}\text { L. innocua (1) L. welshimeri (9) } \\
\text { L. } m(11)(91.30 \%)\end{array}$ & $\begin{array}{l}\text { L. innocua (3) L. welshimeri (4) } \\
\text { L. } m(12)(95.00 \%)\end{array}$ & $55(93.22 \%)$ \\
\hline & $\mathrm{I}=1-2$ & L. $m(1)(14.29 \%)$ & $0(0.00 \%)$ & L. welshimeri $(2)(8.70 \%)$ & L. $m(1)(5.00 \%)$ & $4(6.78 \%)$ \\
\hline & $\mathrm{S}-$ & $0(0.00 \%)$ & $0(0.00 \%)$ & $0(0.00 \%)$ & $0(0.00 \%)$ & $0(0.00 \%)$ \\
\hline \multirow[t]{3}{*}{ VAN } & $R \geqslant 32$ & $0(0.00 \%)$ & $0(0.00 \%)$ & $0(0.00 \%)$ & $0(0.00 \%)$ & $0(0.00 \%)$ \\
\hline & $I=8-16$ & $0(0.00 \%)$ & $0(0.00 \%)$ & $0(0.00 \%)$ & $0(0.00 \%)$ & $0(0.00 \%)$ \\
\hline & $S \leqslant 4$ & $\begin{array}{l}\text { L. innосиа }(1) \\
\text { L. } m(6)(100.00 \%)\end{array}$ & $\begin{array}{c}\text { L. innосиа }(2) \\
\text { L. } m(7)(100.00 \%)\end{array}$ & $\begin{array}{c}\text { L. innocua (1) L. welshimeri }(11) \\
\text { L. } m(11)(100.00 \%)\end{array}$ & $\begin{array}{l}\text { L. innocua (3) L. welshimeri (4) } \\
\text { L. } m(13)(100.00 \%)\end{array}$ & $59(100.00 \%)$ \\
\hline
\end{tabular}

GEN-gentamicin,CAZ-ceftazidime,AMP-ampicillin,CIP-ciprofloxacin,TET-tetracycline,ERY-erythromycin,LIN-lincomycin, VAN-vancomycin 
Table 4 Correlation rate of phenotype and genotype of the Listeria spp.

\begin{tabular}{|c|c|c|c|}
\hline Antibiotics & Resistant strains & Resistance genes & Resistance genes strains \\
\hline \multirow{3}{*}{ Tetracycline } & \multirow{3}{*}{9} & tet $A$ & 36 \\
\hline & & tetM & 24 \\
\hline & & tet $S$ & 0 \\
\hline \multirow[t]{2}{*}{ Ciprofloxacin } & \multirow[t]{2}{*}{57} & $a a c\left(6^{\prime}\right)-I b$ & 4 \\
\hline & & ermA & 10 \\
\hline \multirow[t]{2}{*}{ Eryphilin } & \multirow[t]{2}{*}{4} & ermB & 8 \\
\hline & & erm C & 9 \\
\hline Ceftazidime & 58 & mecA & 0 \\
\hline \multirow{2}{*}{ Vancomycin } & \multirow{2}{*}{0} & $\operatorname{van} A$ & 0 \\
\hline & & van $B$ & 0 \\
\hline
\end{tabular}

396

397

398

399

400

401

402

403

404

405

406

407

408

409

410

411

412

413

414

415

416

417

418

419

420

421

422

423 
Table 5 Primer used in this study for amplification of resistance genes of $L$. monocytogenes

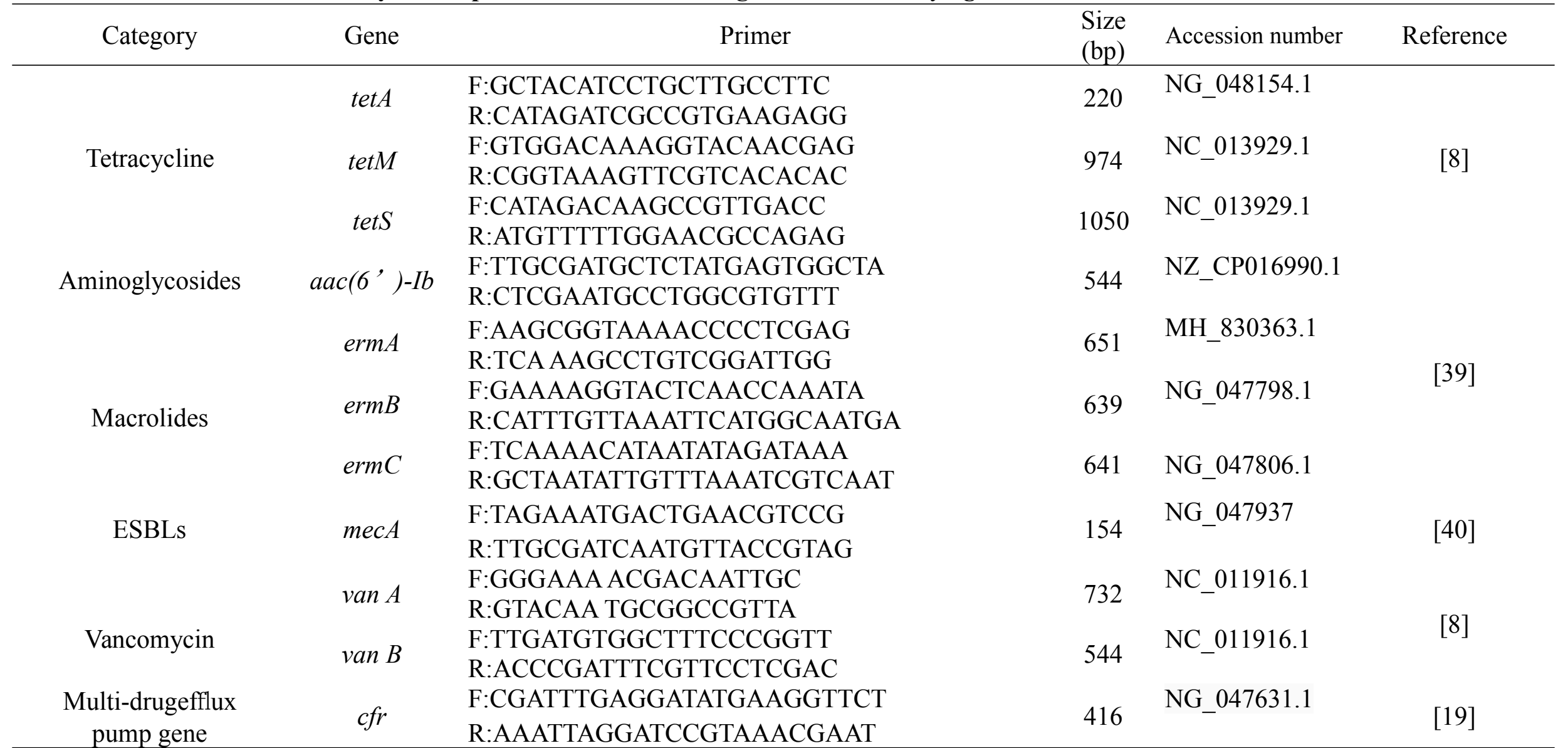


428 Table 6 Primer used in this study for amplification of virulence genes of $\boldsymbol{L}$. monocytogenes

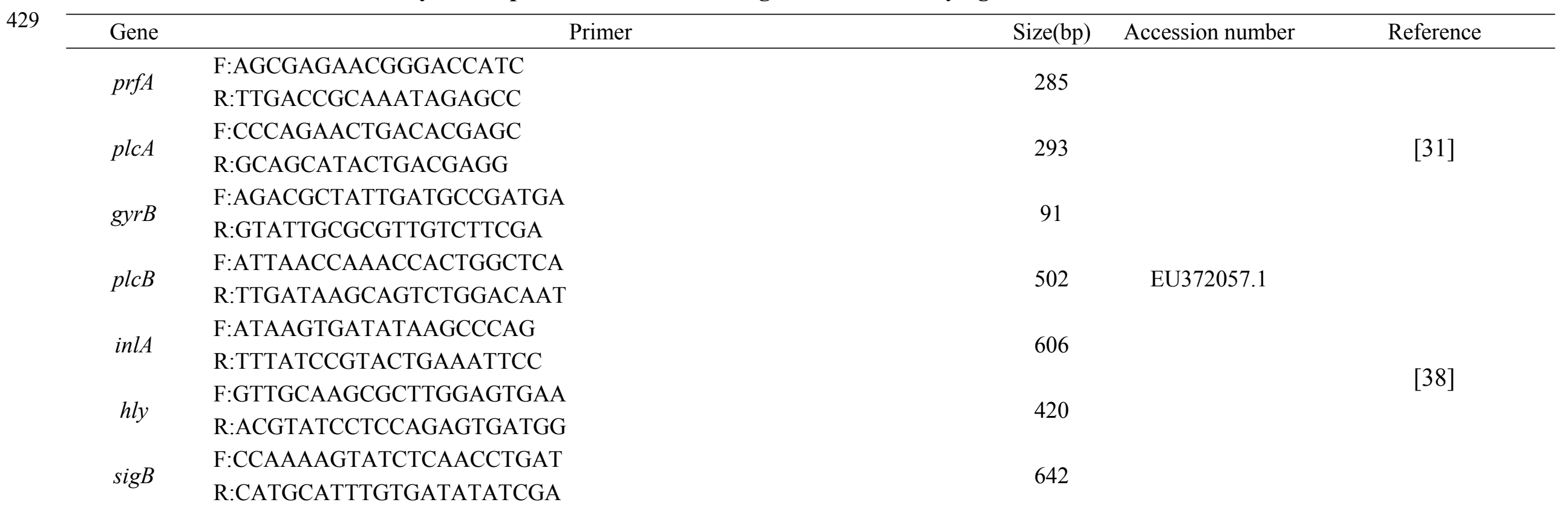




\section{Figure legends}

Fig. 1 Antimicrobial susceptibility of L. monocytogenes isolates from processing plants to eight antibiotics. Gentamicin (GEN), ampicillin (AMP), ceftazidime (CAZ), ciprofloxacin (CIP), tetracycline (TET), erythromycin (ERY), lincomycin (LIN) and vancomycin (VAN) were selected as test antibiotics. A:non-resistance, B:one-resistance, C:two-resistance, D:three-resistance, E:four-resistance, F: five-resistance, G:six-resistance, H:seven-resistance, I:eight-resistance. Streptococcus pneumonia ATCC 49619 was selected as the quality control strain.

Fig. 2 Resistant analysis of $L$. welshimeri, L. inocua and L. monocytogenes. Gentamicin (GEN), ampicillin (AMP), ceftazidime (CAZ), ciprofloxacin (CIP), tetracycline (TET), erythromycin (ERY), lincomycin (LIN) and vancomycin (VAN) were selected as test antibiotics. Streptococcus pneumonia ATCC 49619 was selected as the quality control strain.

Fig. 3 Resistance genotypes of 59 Listeria isolates. Eleven resistance genes tetA, tetM, tetS, erm $A, \operatorname{erm} B, \operatorname{erm} C, \operatorname{aac}\left(6^{\prime}\right)-I b, \operatorname{mec} A, \operatorname{van} A, v a n B$, and $c f r$ were selected as specific resistance genes and were identified by PCR within Listeria spp. . Primers used in this study are listed in Table 5.

Fig. 4 Serotypes, resistance, source, and STs of the Listeria isolates from the processing environment. MLST performed based on seven housekeeping genes (abcZ, bglA, cat, dapE, dat, ldh and $\operatorname{lhk} A$ ) according to the previous method. Genotypic data are available at http://bigsdb.web.pasteur.fr/listeria/. Minimum spanning tree analysis was inferred using BioNumerics (Version 5.10, Applied Maths, Belgium).

ND represents : None determined.

Fig. 5 Invasion level of $L$. monocytogenes isolates against the human colorectal adenocarcinoma cell line Caco-2 cells. In vitro invasion was performed in the Caco-2 cell line $\left(3.0 \times 10^{5}\right.$ cells per well $)$ infected with $1.0 \times 10^{7}-2.0 \times 10^{7} \mathrm{~L}$. monocytogenes cells/well. After contact for $90 \mathrm{~min}$, viable intracellular bacteria 
458 were enumerated by plating appropriate dilutions of the cell lysate on BHI agar.

459 Error bars represent standard deviations of the mean. ATCC19114 strain was

460 included as an invasion control. Significant difference compared with $461 \quad$ ATCC19114; *** $\mathbf{P}<0.01 ; * * \mathbf{P}<0.05 ; * \mathbf{P}>0.05$.

462

463

464

465

Fig. 1

466

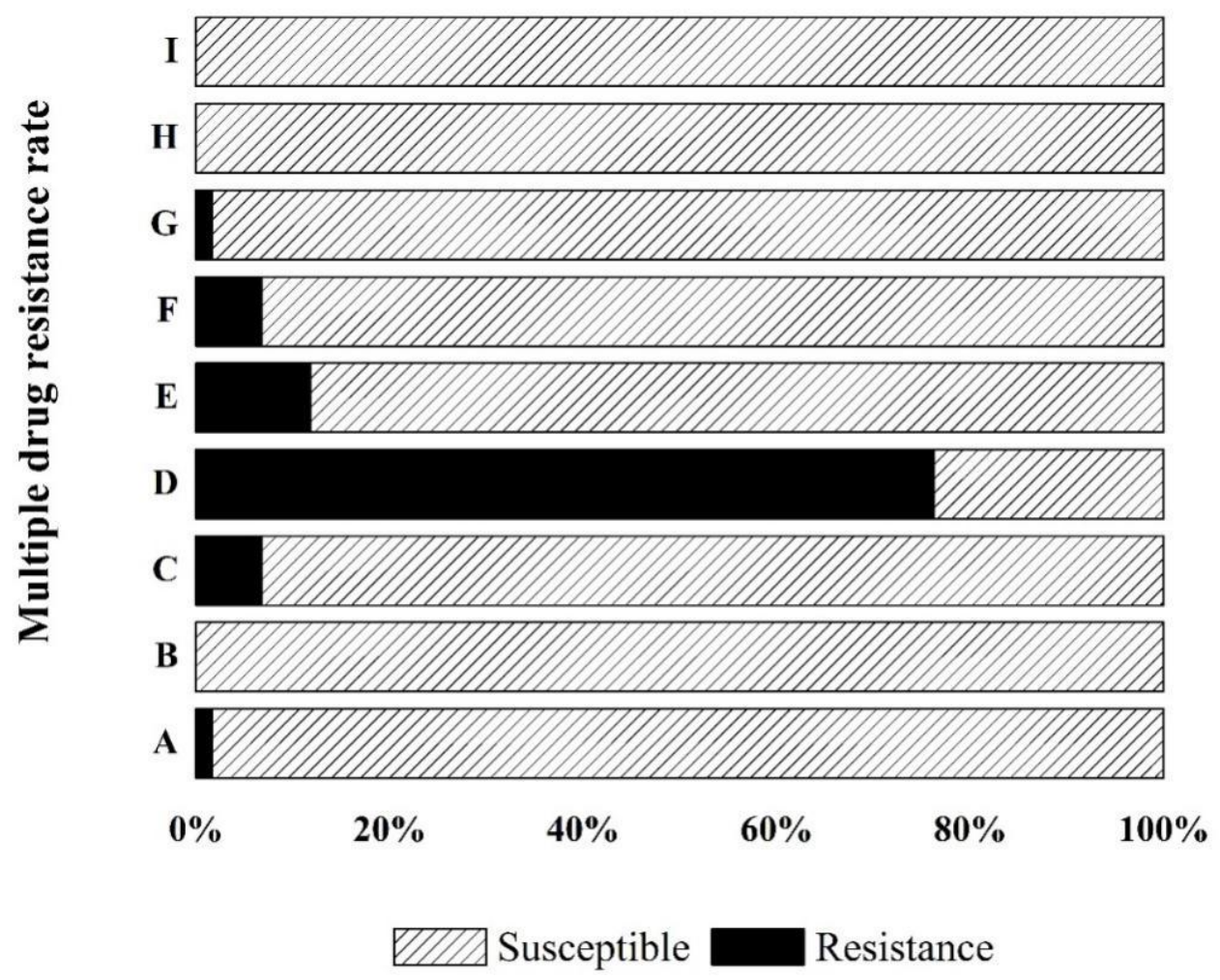




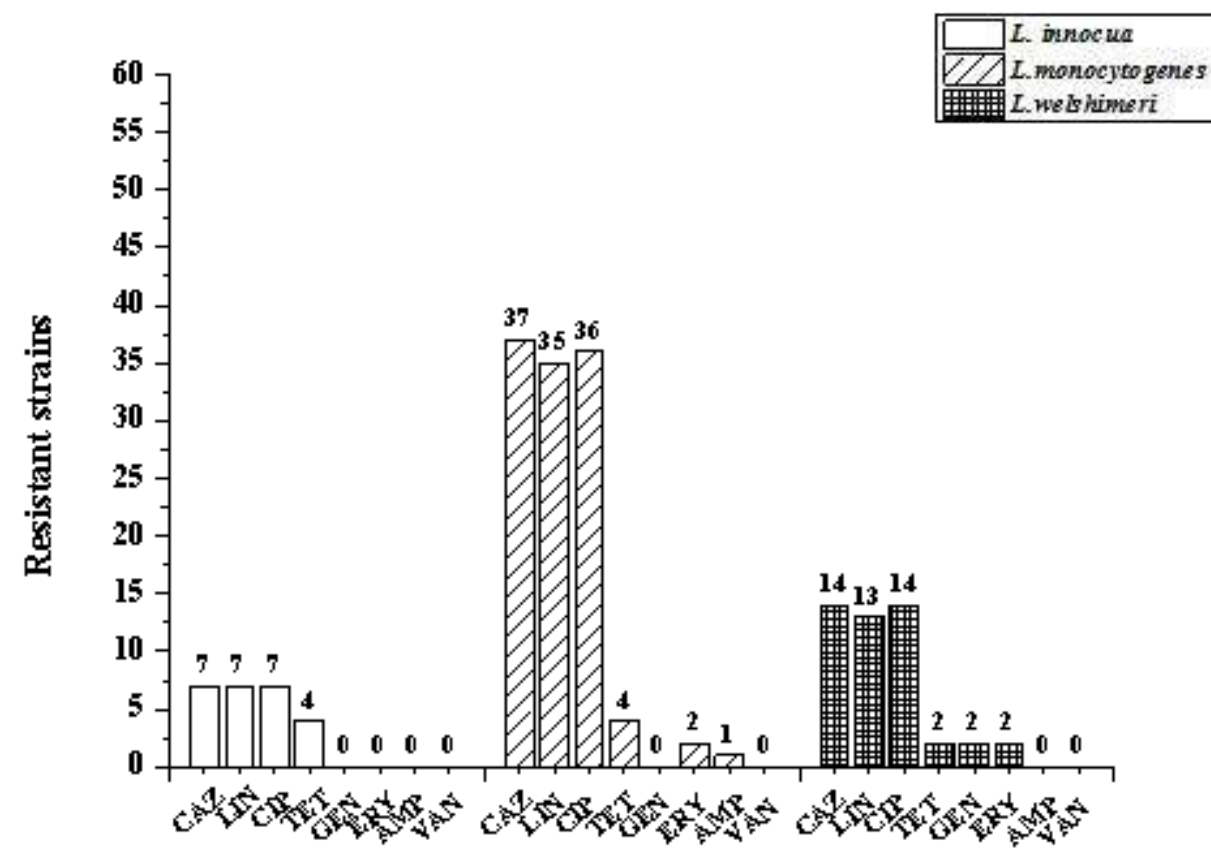

478

479

Fig.3

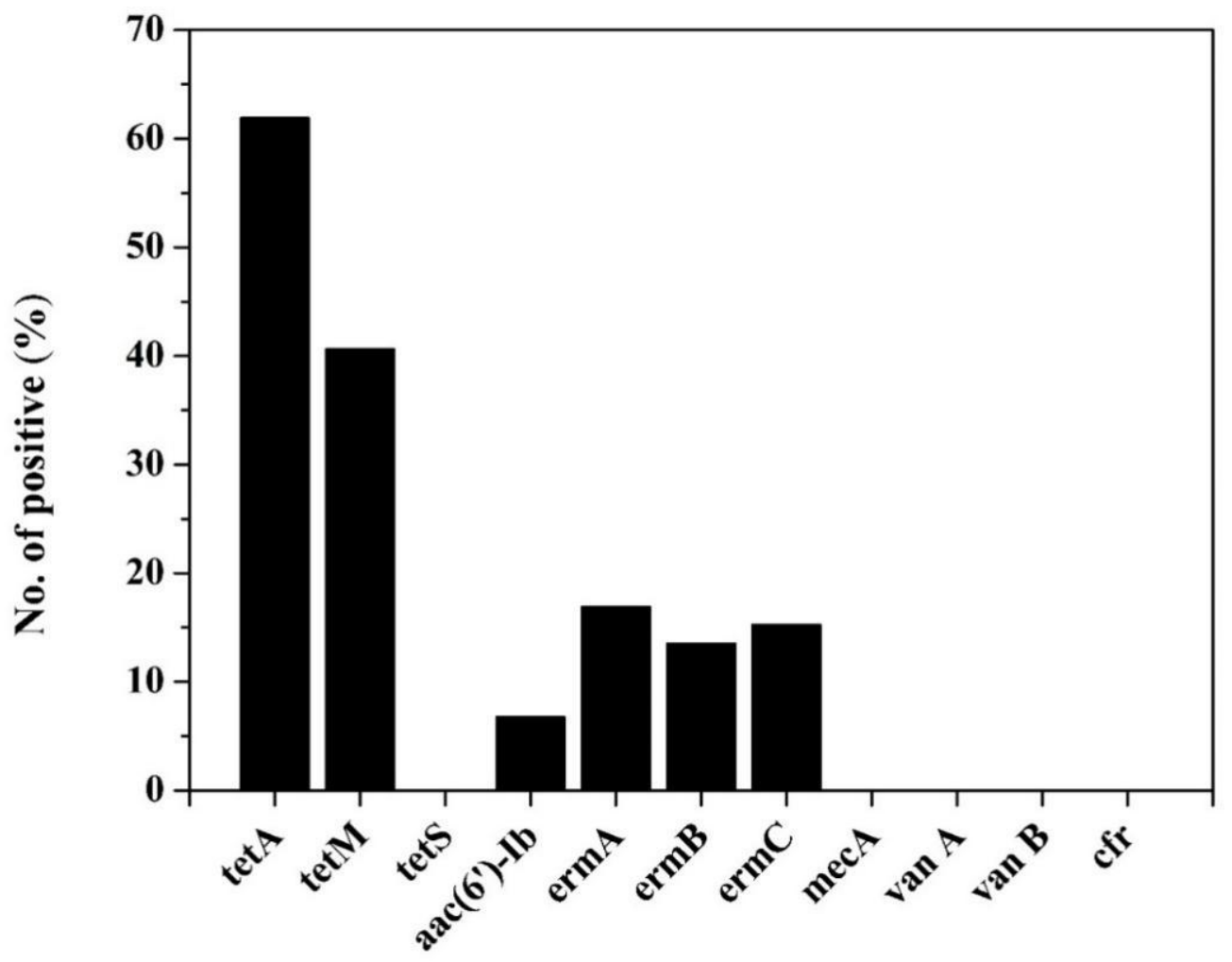

480 


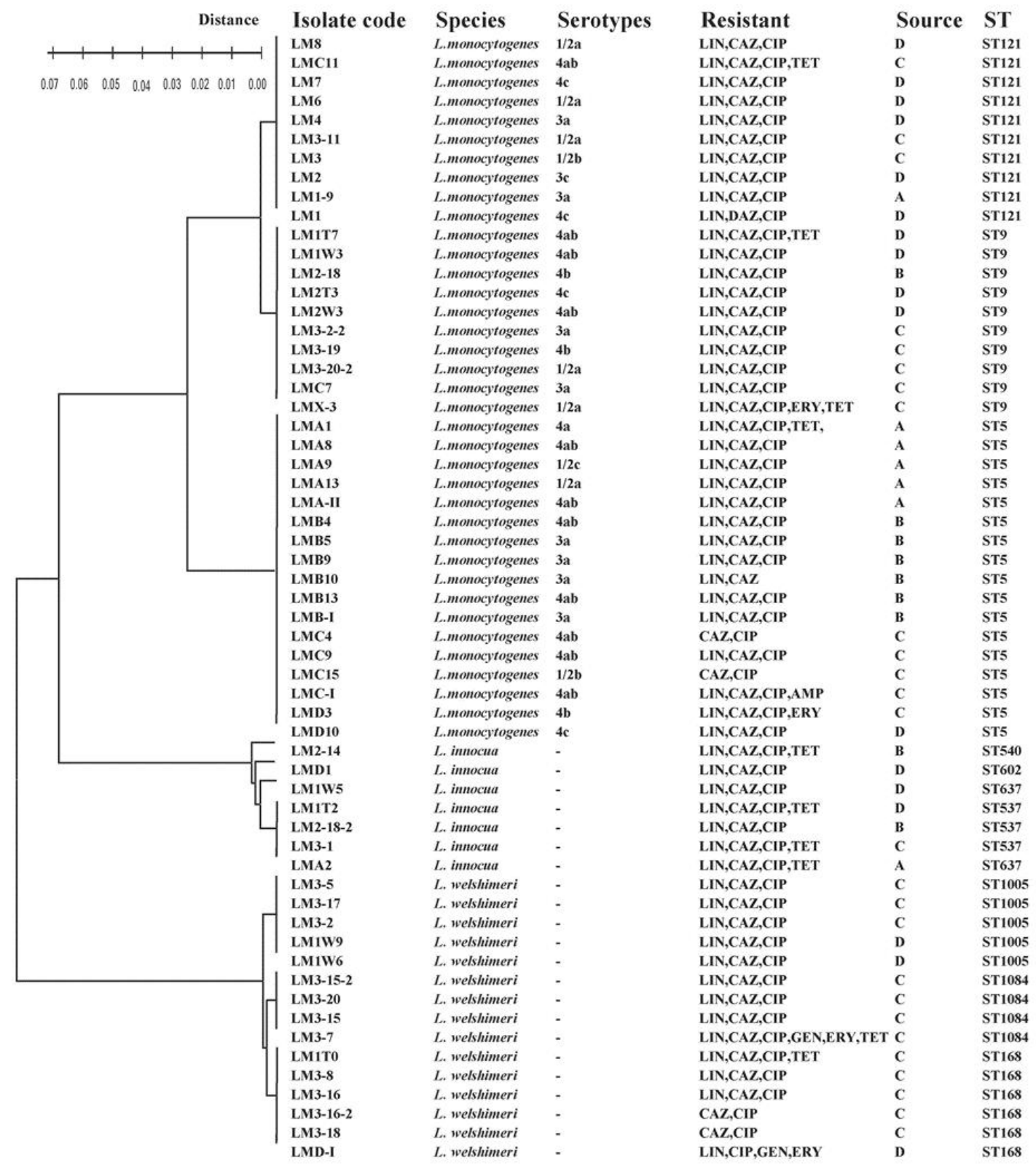




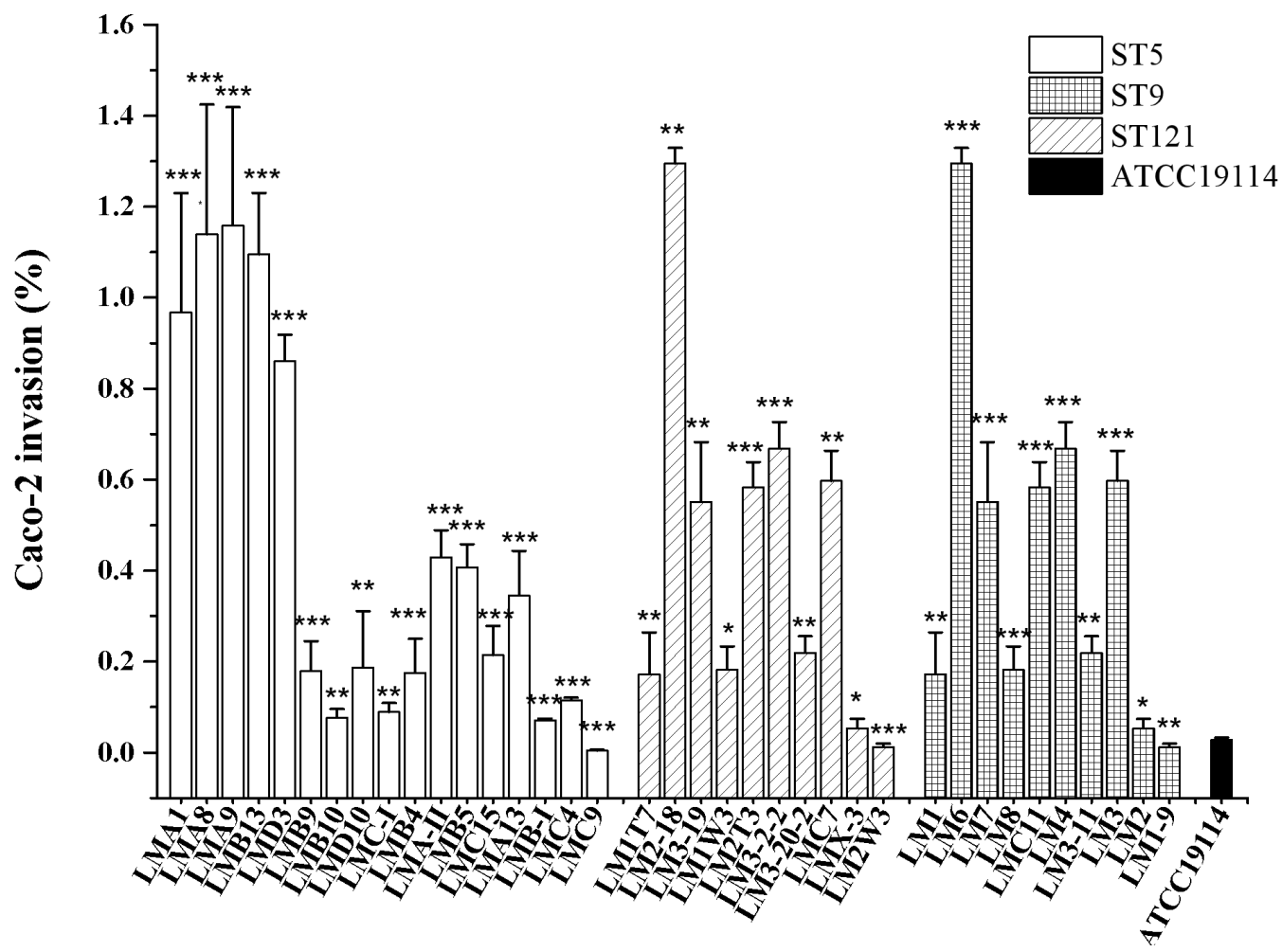




\section{Acknowledgments}

All the author of this manuscript is thankful to Dr. Xiaohui Zhou (University of Connecticut, Storrs, CT 06269) for his suggestions on the revision of this article.

\section{Author contributions:}

Hui Zhang and Liting Wu conceived and designed research. Liting Wu, Mengya Zhu and Tao He conducted experiments. Hongduo Bao, Yan Zhou and Ran Wang contributed new reagents or analytical tools. Zhengquan Yang, Maoda Pang and Yuan Tian analyzed data. Liting Wu and Hui Zhang wrote the manuscript. All authors read and approved the manuscript.

\section{Funding}

This study was supported by the National Natural Science Foundation of China (No. 31671955), the National Key R\&D Program of China (No. 2018YFE0101900), and the Six Talent Peaks Project in Jiangsu Province (No. NY-034).

\section{Competing interests}

There are no conflicts of interest (financial, professional or personal) related to this manuscript.

\section{Availability of data and materials}

Not applicable.

\section{Consent for publication}

Not applicable.

\section{Ethics approval and consent to participate}

Not applicable. 


\section{References:}

1. Rahimi E, Ameri M, and Momtaz H. Prevalence and antimicrobial resistance of Listeria species isolated from milk and dairy products in Iran. Food Control. 2010;21: 0-1452.

2. Jordan K, and Mcauliffe O. Listeria monocytogenes in foods. Advances in Food and Nutrition Research. 2018;86:181-213.

3. Bolocan AS, Nicolau AI, Alvarez-Ordóñez A, Borda D, Oniciuc EA, et al. Dynamics of Listeria monocytogenes colonisation in a newly-opened meat processing facility. Meat Sci. 2016;113: 26-34.

4. Fox EM, Theodore A, Bradbury M, Séamus F, ScottChandry P. Comparative Genomics of the Listeria monocytogenes ST204 Subgroup. Front Microbiol. 2016;7: 1-12.

5. Wu S, Wu Q, Zhang J, Chen M, Guo W. Analysis of multilocus sequence typing and virulence characterization of Listeria monocytogenes isolates from Chinese retail ready-to-eat food. Front Microbiol. 2016;7:00168

6. Doyle MP, Loneragan GH, Scott HM, Singer RS. Antimicrobial resistance: challenges and perspectives. Compr Rev Food Sci F. 2013;12:234-248.

7. Gómez D, Azón E, Marco N, Carramiñana JJ, Rota C, et al. Antimicrobial resistance of Listeria monocytogenes and Listeria innocua from meat products and meat-processing environment. Food Microbiol. 2014;42: 61-65.

8. Li L, Olsen RH, Shi L, Ye L, and He J, et al. Characterization of a plasmid carrying cat, ermB and tet $S$ genes in a foodborne Listeria monocytogenes strain and uptake of the plasmid by cariogenic Streptococcus mutans. Int J Food Microbiol. 2016;238: 68-71.

9. Conter M, Paludi D, Zanardi E, Ghidini S, Vergara A, et al. Characterization of antimicrobial resistance of foodborne Listeria monocytogenes. Int $\mathrm{J}$ Food Microbiol. 2009;128:497-500.

10. Noll M, Kleta S, Al Dahouk S. Antibiotic susceptibility of 259 Listeria monocytogenes strains isolated from food, food-processing plants and human samples in germany. J Infect Public Heal. 2018;11:572-577 . 
11. Lopez-Alonso V, Ortiz S, Corujo A, Martinez-Suarez JV. Analysis of benzalkonium chloride resistance and potential virulence of Listeria monocytogenes isolates obtained from different stages of a poultry production chain in spain. J Food Protect. 2020;83:443-451.

12. Teixeira LAC, Carvalho FT, Vallim DC, Pereira RCL, Neto AC, et al. Listeria monocytogenes in export-approved beef from mato grosso, brazil: prevalence, molecular characterization and resistance to antibiotics and disinfectants. Microorganisms. 2020;8: 11-18.

13. Skowron K, Kwiecińska-Piróg J, Grudlewska K, Świeca A, Paluszak Z, et al. The occurrence, transmission, virulence and antibiotic resistance of Listeria monocytogenes in fish processing plant. Int J Food Microbiol. 2018;282:71-83.

14. Wang G, Qian W, Zhang X, Wang H, Ye K, et al. Prevalence, genetic diversity and antimicrobial resistance of Listeria monocytogenes isolated from ready-to-eat meat products in Nanjing, China. Food Control. 2015;50:202-208.

15. Parisi A, Latorre L, Fraccalvieri R, Miccolupo A, Normanno G, et al. Occurrence of Listeria spp. in dairy plants in Southern Italy and molecular subtyping of isolates using AFLP. Food Control. 2013; 29: 91-97.

16. Martín B, Garriga M, Aymerich T. Prevalence of Salmonella spp. And Listeria monocytogenes at small-scale spanish factories producing traditional fermented sausages. J Food Protect. 2011;74:812-815.

17. Sakaridis I, Soultos N, Iossifidou E, Papa A, Ambrosiadis I, et al. Prevalence and antimicrobial resistance of Listeria monocytogenes isolated in chicken slaughterhouses in Northern Greece. J Food Protect. 2011;74:1017-1021.

18. Williams SK, Roof S, Boyle EA, Burson D, Thippareddi H, et al. Molecular ecology of Listeria monocytogenes and other Listeria Species in small and very Small ready-to-eat meat processing plants RID A-9683-2008. J Food Protect. 2011;74: 63-77.

19. Du X, Zhang X, Wang X, Su Y, Li P, et al. Isolation and characterization of Listeria monocytogenes in Chinese food obtained from the central area of China. 
Food Control. 2017;74: 9-16.

20. Graves LM, Swaminathan B, Hunter SB. " "Subtyping Listeria monocytogenes," in. (CRC Press, Taylor and Franscis Group, Boca Raton: New York), 2007;283-304.

21. Viswanath P, Murugesan L, Knabel SJ, Verghese B, Chikthimmah N, et al. Incidence of Listeria monocytogenes and Listeria spp. in a Small-Scale Mushroom Production Facility. J Food Prot. 2013;76: 608-615.

22. Martín B, Bover-Cid S, Aymerich T. MLVA subtyping of Listeria monocytogenes isolates from meat products and meat processing plants. J Food Protect. 2018;106: 225-232.

23. Henriques AR, Gama LT, Fraqueza MJ. Tracking Listeria monocytogenes contamination and virulence-associated characteristics in the ready-to-eat meat-based food products industry according to the hygiene level. Int J Food Microbiol. 2016;242:101.

24. Jang HM, Kim YB, Choi S, Lee Y, Shin SG, et al. Prevalence of antibiotic resistance genes from effluent of coastal aquaculture, south korea. Enivron Pollut 2018;233:1049-1057.

25. Suzuki S, Hoa PTP. Distribution of quinolones, sulfonamides, tetracyclines in aquatic environment and antibiotic resistance in Indochina. Front Microbiol. 2012;3:1-8.

26. Haubert L, Cunha CEPD, Lopes GV, Silva WPD. Food isolate Listeria monocytogenes harboring tetM gene plasmid-mediated exchangeable to Enterococcus faecalis on the surface of processed cheese. Food Res Int. 2018;107:503-508.

27. Suzuki S, Makihara N, Kadoya A. Tetracycline resistance gene tet(M) of a marine bacterial strain is not accumulated in bivalves from seawater in clam tank experiment and mussel monitoring. Sci Total Environ. 2018; 634181-187.

28. Vester, B. The $c f r$ and cfr-like multiple resistance genes. Res Microbiol. 2018; $169: 61-66$.

29. Yadav MM, Roy A, Bhanderi B. Multiple antibiotic resistance among Listeria 
strains, including listeria monocytogenes isolated from animals of gujarat state, india. Int J Curr Microbiol Appl Sci. 2018;7:1493-1501.

30. Kumar R, Agarwal RK, Bhilegaongar KN, Garg AP, Tyagi KP. Occurrence of multidrug resistant Listeria spp. in meats and fish. Public Health 2005; 3:13-18.

31. Kanki M, Naruse H, Taguchi M, Kumeda Y. Characterization of specific alleles in InlA and PrfA of Listeria monocytogenes isolated from foods in Osaka, Japan and their ability to invade Caco-2 cells. Int J Food Microbiol. 2015;211:18-22.

32. Charpentier E, Courvalin P. () Antibiotic resistance in Listeria spp.. Antimicrob Agents Ch. 1999;43:2103-2108.

33. Wang Y, Zhao A, Zhu R, Lan R, Jin D, et al. Genetic diversity and molecular typing of Listeria monocytogenes in China. BMC Microbiol. 2012;12:119-119.

34. Oxaran V, Lee SHI, Chaul LT, Corassin CH, Barancelli GV, et al. Listeria monocytogenes incidence changes and diversity in some Brazilian dairy industries and retail products. Food Microbiol. 2017;68:16-23.

35. Wu S, Wu Q, Zhang J, Chen M, Guo W. Analysis of multilocus sequence typing and virulence characterization of Listeria monocytogenes isolates from Chinese retail ready-to-eat food. Front Microbiol. 2016;7:1-11.

36. Cao X, Wang Y, Wang Y, Ye C. Isolation and characterization of Listeria monocytogenes from the black-headed gull feces in Kunming, China. J Infect Public Health. 2018;11:59-63.

37. Antunes P, Reu C, Sousa JC, Pestana N, Peixe L. Incidence and susceptibility to antimicrobial agents of Listeria spp. and Listeria monocytogenes isolated from poultry carcasses in porto, portugal. J Food Protect. 2002;65:1888.

38. Buchanan RL, Gorris LGM, Hayman MM, Jackson TC, Whiting RC. A review of Listeria monocytogenes: An update on outbreaks, virulence, dose-response, ecology, and risk assessments. Food Control. 2017;75:1-13.

39. De Vasconcelos Byrne V, Hofer E, Vallim DC, De Castro Almeida RC. Occurrence and antimicrobial resistance patterns of Listeria monocytogenes isolated from vegetables. Bra J Microbiol. 2016;47:438-443.

40. Rückerl I, Muhterem-Uyar M, Muri-Klinger S, Wagner KH, Wagner M, et al. L. 
monocytogenes in a cheese processing facility: Learning from contamination

654 scenarios over three years of sampling. Int J Food Microbiol. 2014;189:98-105. 655 
Figures

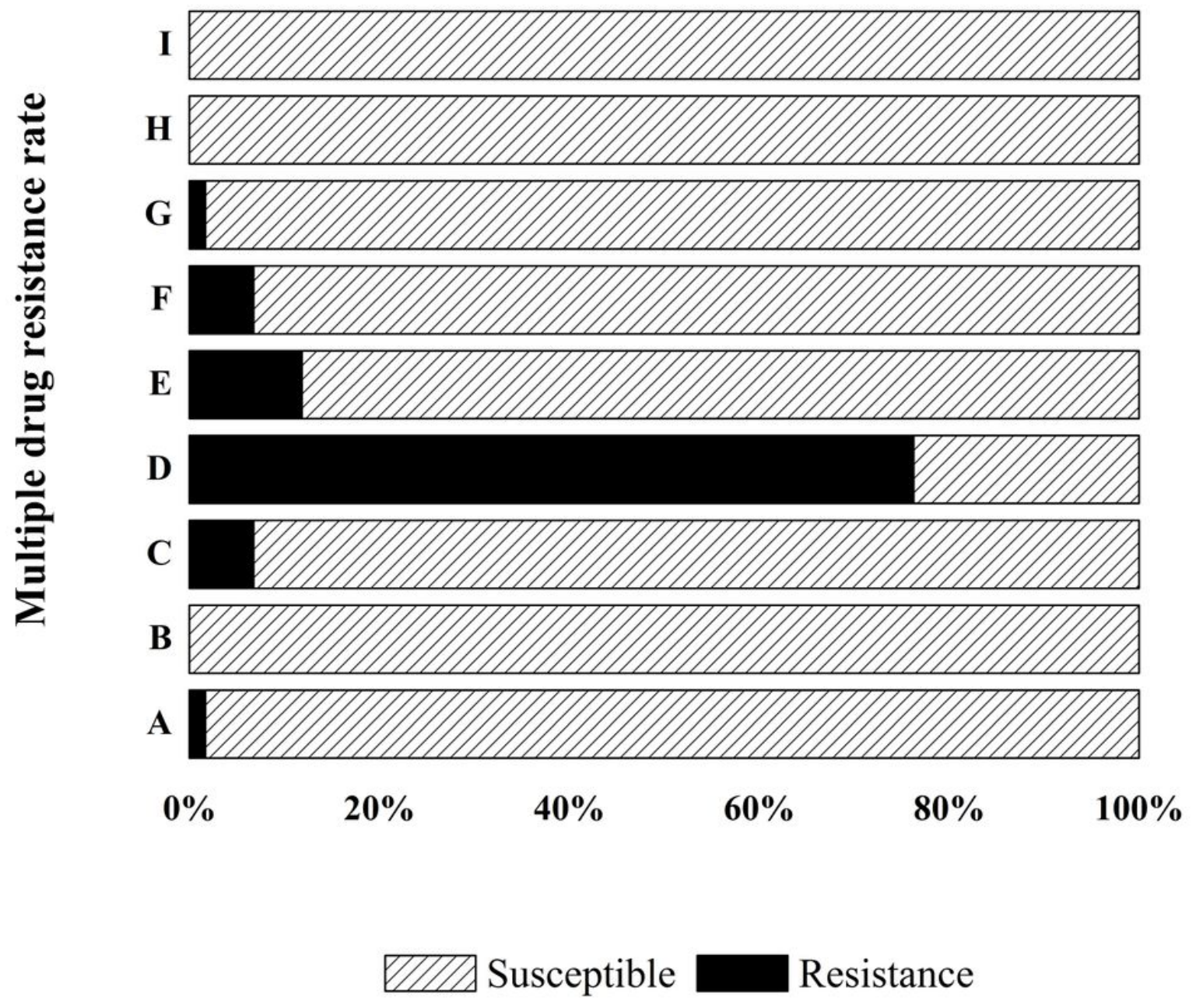

Figure 1

"Please see the Manuscript PDF file for the complete figure caption". 


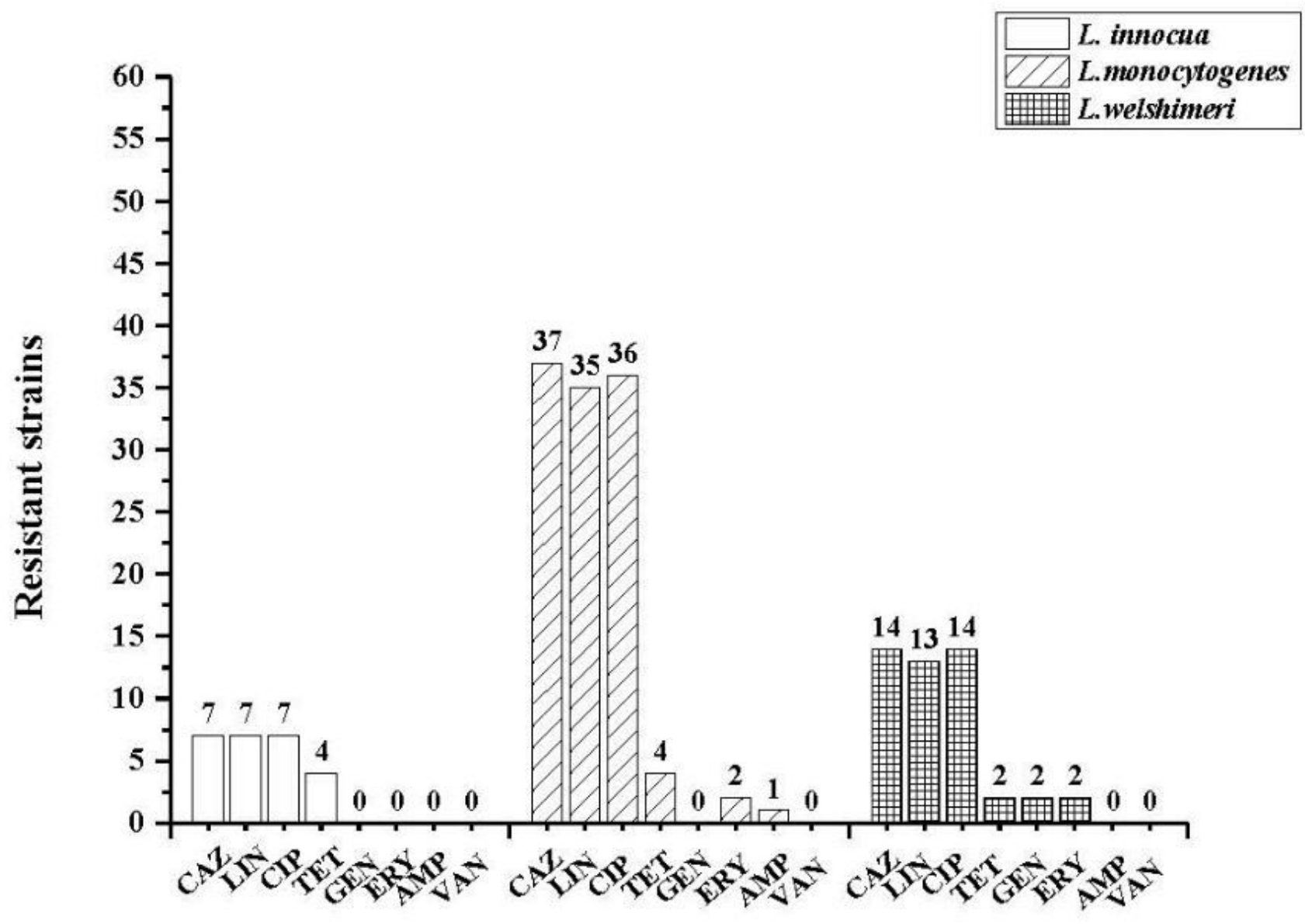

Figure 2

"Please see the Manuscript PDF file for the complete figure caption". 


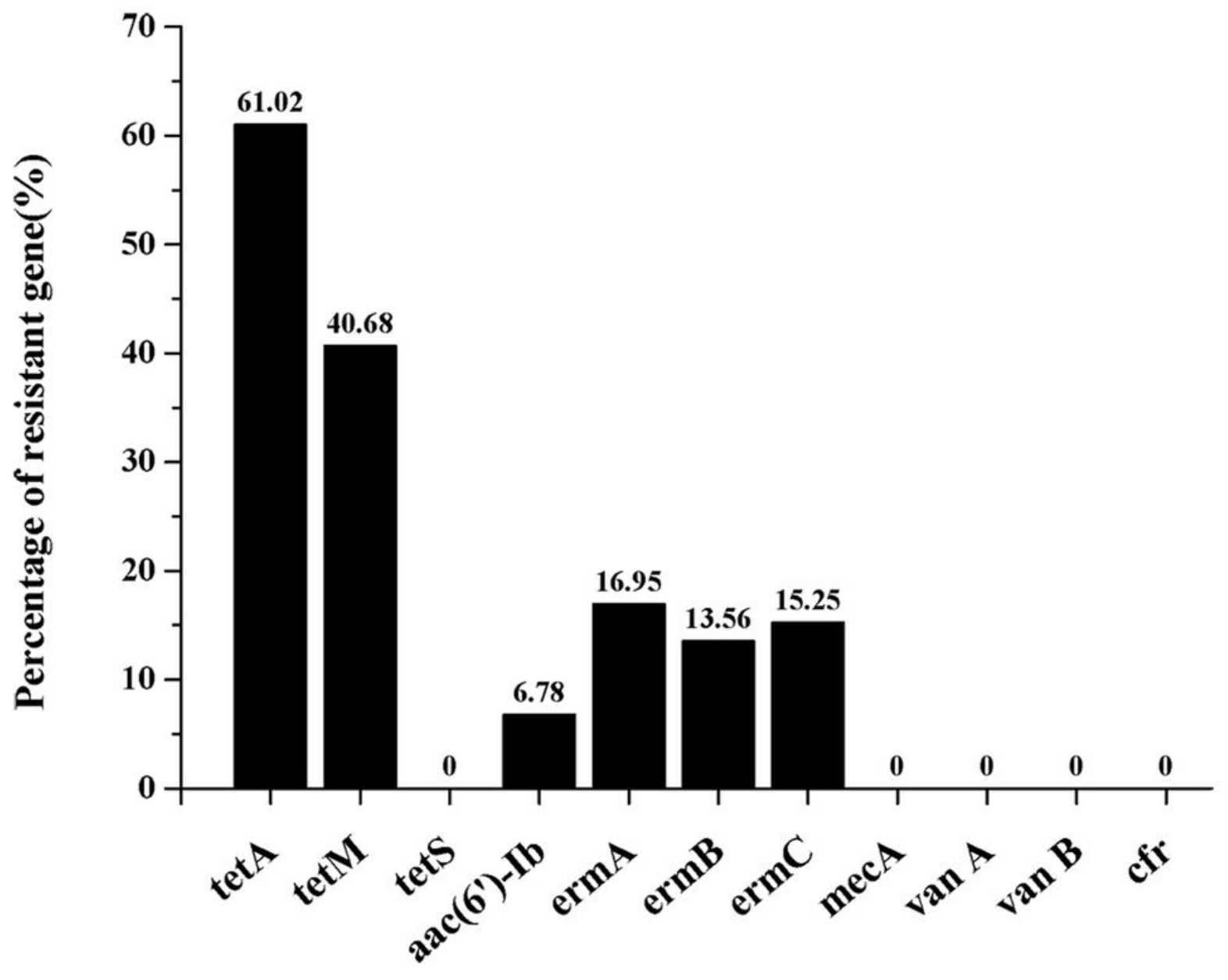

Figure 3

"Please see the Manuscript PDF file for the complete figure caption". 


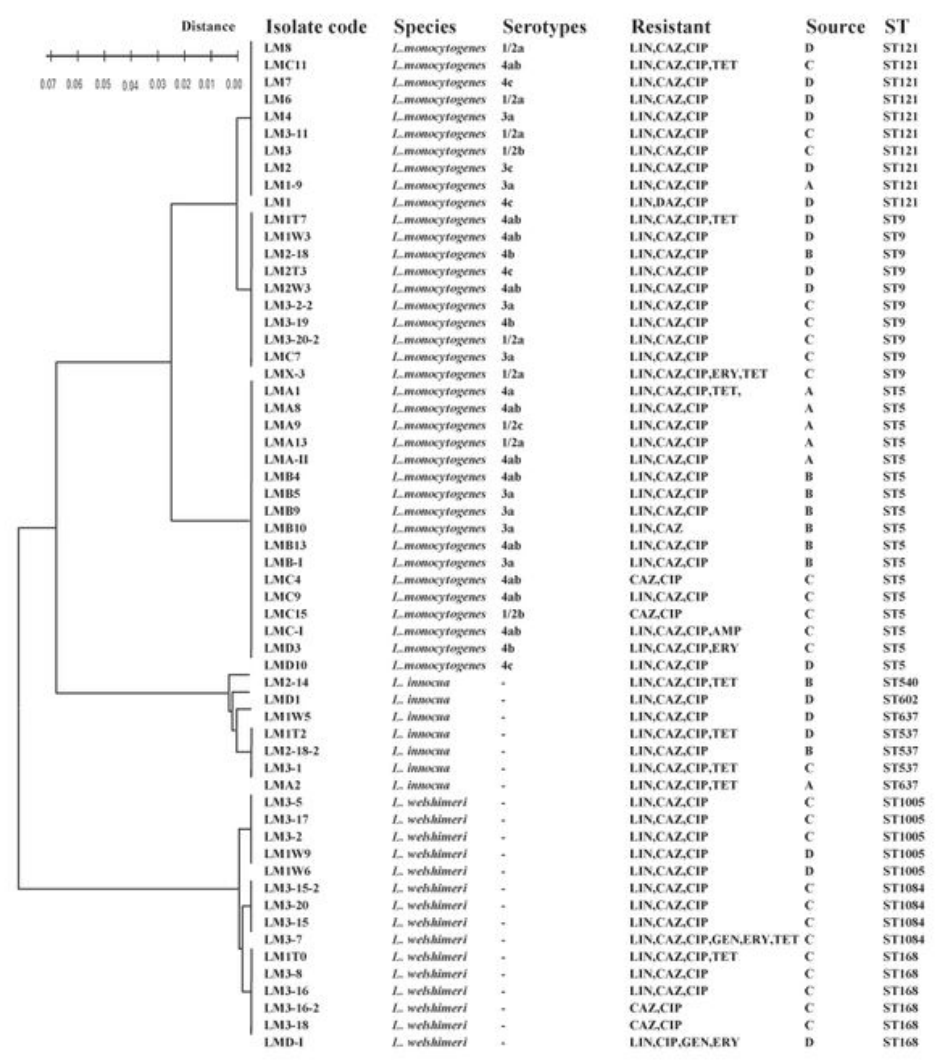

Figure 4

"Please see the Manuscript PDF file for the complete figure caption". 


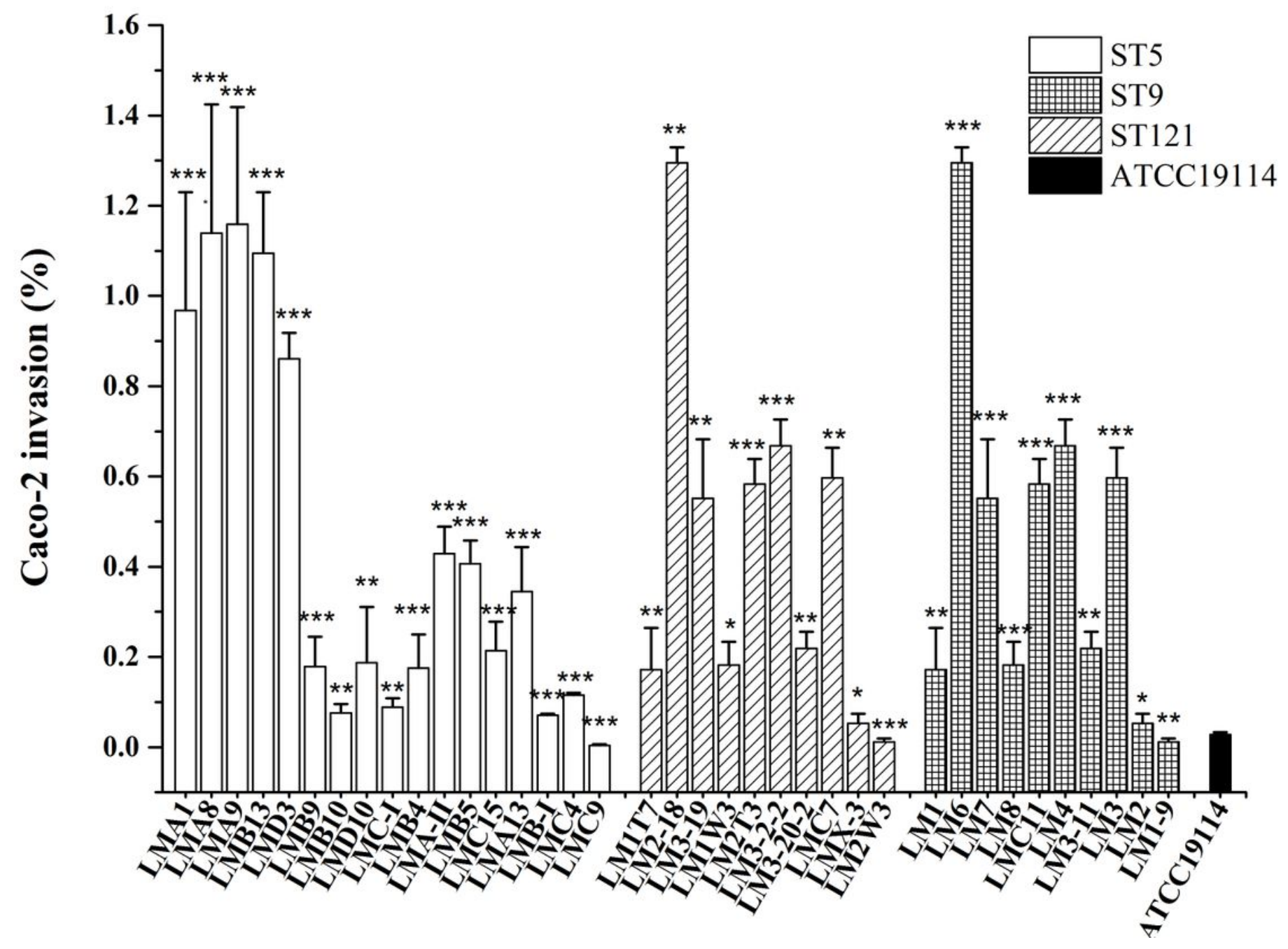

Figure 5

"Please see the Manuscript PDF file for the complete figure caption". 